\title{
Extremophile Current Challenges and New Gate of Knowledge by Nanoparticles Pathways.
}

\author{
Waznah Moayad ${ }^{1,2,}$ Genhan Zha ${ }^{1}$ and Yunjun Yan ${ }^{1 *}$ \\ ${ }^{1}$ Key Laboratory of Molecular Biophysics of the Ministry of Education, College of Life Science and Technology, \\ Huazhong University of Science and Technology, Wuhan, 430074, P. R. China \\ ${ }^{2}$ Biology Department, College of Science, TaibahUniversity, Madinah, Kingdom of Saudi Arabia
}

\begin{abstract}
Extremophiles are a unique organisms that have ability to exist in critical environmental conditionssuch as temperatures, $p H$, saline and pressures.They are characterized by high efficiencies in growth and enzymes product that led them to be a candidate in industrial productions as detergents, brewing, cosmetics, dairy products, bakery, textiles, and as degradation materials.. More information concerning the behavior of extremophiles is still required. Recently, several studies are conducted to detectdeep information about extremophiles using the advantages of nanoparticles. For instances, gold $(\mathrm{Au})$ and silver $(\mathrm{Ag})$ nanoparticles open a new gate of knowledge for researcher particularly for study different pathways of extremophiles. In this review we first concerns with extremophiles definition, history and applications then we reflects general idea about the environmental conditions taking in account the uses of nanoparticles.
\end{abstract}

Keywords: Extremophiles, microorganisms, applications, nanoparticles.

\section{Definition}

In nature, there are several kind of environmental conditions and resources such as temperature, $\mathrm{pH}$, pressure, salinities, desiccation, radiation and metal.Thesecan effect survival ratio ofliving organisms, plants and animals.Due to the different values of physico-chemical and survival conditions, the relationships between environmental situationsare definitely complicated. To understand that, we have to know the normal range for every conditions and resources includingthe efficiency ofa variety lives. However, abnormal range of conditions and resources could be optimum environments for different organisms to survive. These kind of organisms are known as extremophilesor briefly, the organisms which have ability to be active in abnormal environments[1].

\section{Background}

Farlow was the owner for first extremophile species isolated from salted fish which described as a salted-loving organisms (halophilic)[2]. In 1936, up to 34\% salted concentration resistance strains have been isolatedfrom the Dead-sea byEleazari Volcani [3]. He showed the improper appellation of that kind inwater body. Volcani is consideredas historical leader due to his efforts since he got the starting point in extremophilic field and focused in halophilic microbes. Since halophilic organisms start to be interesting for researchers and had more attentions until they revealed that the majority of them follow the third sphere of existence which have been identified as archaea [4]. During that decade, hyperthermophilic and thermophilic microbes were isolated at 60 to $80^{\circ} \mathrm{C}$. Furthermore, in 1969, Thermus aquaticus thermophilic bacterium was isolated by Thomas Brock fromYellowstone National Park hot spring in the United States [5]. After one year, Sulfolobus acidocaldarius was the first hyperthermophile isolated which able to raising in low $\mathrm{pH}(1-5)$ and up to $85^{\circ} \mathrm{C}$ [6]. Accordingly, this was a large discovering for biologists because its changed all the previous concepts,there are no organisms can resist higher than $80{ }^{\circ} \mathrm{C}$ [7]. These discoveries were the first extremophile approaches that develops the diversity of microbiology. In the following section, we discuss more details about the extremophile environmental conditions.

\subsection{Temperature}

\section{Different Environmental Conditions And Enzymes}

The environmental temperature is essential factor for organisms to survive and growth. There are minimum, optimum and maximum temperatures, and eachorganism has its characteristic temperaturefor growth and survival. 
Extremophile Current Challenges and New Gate of Knowledge by Nanoparticles Pathways.

\subsubsection{High Temperature}

Organisms that able to survive and grow into thermal area are called thermophilic.according to their resistanceto temperature,thermophilic organismsare divided into three groups: 1) mesophilic has an optimum between 50 to $60^{\circ} \mathrm{C}, 2$ ) thermophilic has an optimum higher than $70^{\circ} \mathrm{C}$, and 3) hyperthermophilic which has an optimum temperature more than $80^{\circ} \mathrm{C}$ [8]. It was found that prokaryotic (Bacteria and Archaea) can grow in much higher temperature $\left(113^{\circ} \mathrm{C}\right.$ ) than eukaryotic (not over $\left.60^{\circ} \mathrm{C}\right)[9]$. Thermophilic bacteria such asThermoanaerobacteriales, Bacillales, and Clostridiales were isolated from a variety of environmental and also ordered as alkaliphiles, neutrophils and acidophiles; strict anaerobes, selective anaerobes, and aerobes; and chemolithotrophs and chemoorganotrophs [10].

High percentage of hyperthermophilic isolated from terrestrial and marine thermal area [11]. Hyperthermophiles are very diversity in physiological properties and phylogeny. Now, novel taxonomy had recognized and characterized by using $16 \mathrm{~S}$ rRNA sequenced-based of prokaryotes. Further, to acquiring more efficiency resolution of taxonomy by using several kinds of traditional taxonomic features like physiological features, morphology, DNA-DNA homology and GC content DNA [12]. Phylogenetic tree of the 16S rRNA-based presented that, it has three domains, the eukarya, bacteria, and archaea (the former 'archaebacterial') [13]. In the branches root cluster, hyperthermophiles appear as a short deep phylogenetic branches in the domains of bacteria and archaea. In fact, the highest growth temperatures are the members of the shortest and deepest lineages [14]. Accordingly, the eukaryotic has no short deep lineage, that mean it cannot survive as hyperthermophilic due to the limitation of membrane system adaptation [15]. In hyperthermophilicbacteria, there are 10 orders including 29 genera, and more than 70 species [16]. Some examples of such bacteria are Thermocrinis rubber, T. neapolitana, Thermotoga maritima, Fervidobacterium pennavorans, A. profundus, and Aquifl expyrophilus [17]. Among these species, T.maritima and A. pyrophilusshows the highest growth temperatures $\left(90\right.$ and $95^{\circ} \mathrm{C}$,respectively).In Archaea, which represent the majority of hyperthermophiles the genera Desulforococcus, Thermococcus, Thermoproteus, Sulfolobus, Pyrobolus, Pyrococcus, Pyrodictium, Pyrobaculum, Ferroglobus, and Archaeoglobus are grown above $80{ }^{\circ} \mathrm{C}$. However, P. fumari and P.occultumrecorded the highest temperature $\left(113\right.$ and $121{ }^{\circ} \mathrm{C}$, respectively)[18].

Thermophilic enzymes have gotten much attention than others. Lipases, polymer-degrading enzymes (amylase, cellulose, and chitinases), and proteases, were a particularthermophilic enzymes. Thus, they display as industrial application enzymes[19]. For an examples, proteases can be used in detergents, brewing, hydrolysis in feed and food, and baking.Glycosyl hydrolysis (e.g.xylanases, cellulases, glucosidases, glucoamylases, pullulanase, and amylases) using for textiles, pectin, chitin, cellulose, starch, and processing. Chitin modification for food and health products, have been produced by chitinases, and also paper bleaching by xylanases. Stereo-specific reactions (e.g. trans-esterification, organic biosynthesis) and detergents were produced by lipases and esterases [20].Furthermore, DNA polymerase (e.g. Taq polymerase) produced by Thermophilusaquaticuscould be classified as thermophilic enzymes [21]. Researchers were exploiting thermal enzymes that are active and stable at elevated temperature due to the solubility of reaction components and reduction of contamination. It was concluded that, in structural studies of thermophilic enzymes the stability was accomplished by a combination of replacement of uncovering 'thermolabile' amino acids, increased the hydrophobicity of protein core, and increased the charge of surface [22-24].

\subsubsection{Low temperature}

Low temperature can be considered as a risk for all organism's activities and occurrences. Organisms which growth in cold environment could be inhabit in mountainous zonesand Polar Regions[25]. The most part of the earth which has low temperature is ocean due to it is covering 3 quarter of the earth surface. The average of ocean's temperature is $5^{\circ} \mathrm{C}$ but the depth average is $1-2^{\circ} \mathrm{C}$.Especially when it start freezing due to the lower temperature. In such environmental condition the growth is suspended, and then the intracellular become as water solidifies. The freezing point could be lowered until the values become below $0^{\circ} \mathrm{C}$ by the occurrence of great concentrations of solutes, which behave as antifreeze solutions. The freezing point has an ability to inhibit organisms and a part of continents can be characterized as low temperature. Accordingly, psychrophilic organisms could be reported in the permafrost of Siberia and Antarctica[26]. Microorganisms can be survive and adapted the cold conditions but it is very hard to distinguish that microorganisms live as psychrophiles or psychrotolerantincold environment [27]. The snow algae and eukaryotic can be colonized in the ice such as the color of red, orange, or green snow due to the pigment of algae. For example,Chlamydomonas nivalis whichpresented its color at $1{ }^{\circ} \mathrm{C}$. On the other hand, a large number of bacteria is often live in sea ice (exactly, in ice pocket liquid) [28]. Cowan et al, found that in permanently cold (the ratio of temperature at -0.5 to $3.8^{\circ} \mathrm{C}$ ) Antarctic soils, the living bacteria can be ascertained $3 \times 10^{6}$ and $2 \times 10^{9} \mathrm{by}$ the determination of bioluminescent ATP.Higher numbers of bacteria appearing well in permafrost soils [29]. More surprising activities in permafrost by the communities of microbes are that, the lipid fractions which have been incorporation by ${ }^{14} \mathrm{C}$-labeled acetate enabled the appraisal of the community lower doubling 
periods for 160 days at $-20^{\circ} \mathrm{C}$, for 20 days at $-10^{\circ} \mathrm{C}$, and for 1 day at $5^{\circ} \mathrm{C}$ [30]. Irgens et al, have been found that in Antarctic marine water is the most popular place for psychrophilic microorganism, a part of the $\gamma$-Proteobacteria called Polaromonas vacuolata, which can grow up in the range of $0-12^{\circ} \mathrm{C}$ andthe optimum temperature is $4^{\circ} \mathrm{C}[31]$. Also psychrophilic enzymes have appeared in industrial field as lipases, proteases, amylases and cellulases.These enzymesparticipate in different manufacturing such as dairy products, bakery, and textiles or mayshares in detergents andcosmetics. In structural studies, there is assumption that psychrophilic enzymes decreased the stability and correlated with increased flexibility[27].

\section{$3.2 \mathrm{pH}$}

A life of microbial is achievable bya wide values of $\mathrm{pH}$. Organisms which being in low $\mathrm{pH}$ environment called acidophiles, whilethe organisms living in high $\mathrm{pH}$ environments are termed alkaliphiles.

\subsubsection{Acidity}

The acidity of environments can be increased by biological factorsor abiotically(volcanic area has the solfatara fields)., For instance, the chemoautotrophic bacteria (Thiobacillus ferrooxidans or Thiobacillus thiooxidans) has ability to oxidize pyrite, elemental sulfur, sulfide, and other chemical compounds leading to the $\mathrm{pH}$ reduction by accumulationa concomitant with sulfuric acid. Acidity production could also resulted from organic acids during fermentation or ferrous iron oxidation.For example, Thiobacillus ferrooxidans generates 380 acids that precipitates in protons release such as $\mathrm{Fe}(\mathrm{OH})_{3}$ through the oxidation of $\mathrm{Fe}^{2+}$ to $\mathrm{Fe}^{3+}$

Acidophilic microorganisms can be found in three domains: Eukarya, Bacteria, and Archaea. Eukaryotes have heterotrophic and phototrophic, extremely acid-tolerant and/or acidophilic. Dunaliella acidophila as a unicellular green alga needs acidic conditions between $\mathrm{pH} 0$ to 3 and the optimum $\mathrm{pH}$ is 1.0 [32]. The clusterof acidophilic and thermophilic are often occurs through different microorganisms particularly in algae[33]. The thermoacidophilic of a unicellular alga (e.g.,Cyanidium caldarium)can tolerates the acidity of $\mathrm{pH}(0.2)$ andthe optimum growth in the range of $\mathrm{pH} 2-3$ [34, 35]. This kind of acidophilic alga can tolerate $1 \mathrm{~N}$ sulfuric acid. A few number of fungi may growing at $\mathrm{pH}$ values near zero e.g., species of the genera Trichosporon, Cephalosporium, and Acontium. The bacterial domain as mentioned previously (Leptospirillumferrooxidans and Thiobacillusferrooxidans) could be grown at $\mathrm{pH}$ 2-4.Furthermore, Thiobacillusthiooxidanscould be grown at lower $\mathrm{pH} 0.5$.

Among the microorganisms, archaeal domain is the most acid-tolerant and acidophilic. Up to date, Picrophilustorridus and Picrophilusoshimae (hyperacidophilic species) were able to grow in the lowest reported $\mathrm{pH}$, that is -0.06 , the optimum $\mathrm{pH}$ at 0.5 and the cells lyses above $\mathrm{pH} 4$. In addition, the archaea require high temperature and $60^{\circ} \mathrm{C}$ is considered as an optimum temperature for growing. An aerobic heterotrophs of Picrophilus, isolated from Japanese solfatara,can grow on yeast extract as energy and carbonsources[36-38]. Also numerous of thermos-acidophilic archaea such as Thermoplasmaacidophilum has an optimum $\mathrm{pH}$ for growth at 1.8-2 and $\mathrm{pH} 0.4$ isthe minimum value for growth [39].Also several biocatalysis enzymes are active at low $\mathrm{pH}$ such asglucosidases, glucoamylases, pullulanases, oxidases, cellulases, proteases and amylases.These enzymes have been used in different applications including starch processing,desulfurization of coal, and feed component [40, 41].

\subsubsection{Alkalis}

Alkaliphilic bacteria,growing at $\mathrm{pH}$ 9-10 and above, can be isolated from soil or fromother environmental resources. For example, Bacillusalcalophilusis the popular organism that used to study the adaptation of alkali values (pHexceeding ten) depending on bioenergetics aspects. In soda lakes, more extreme alkaliphiles can be found at $\mathrm{pH}$ 12. Many distinct kinds of metabolism that support elements in complete cycling such as sulfur, nitrogen, and carbon have been expressed by existence of alkaliphiles [42, 43].In archaeal domain, there are some species have obligate alkaliphiles such as haloalkaliphilic genera Natronococcus and Natronobacterium, that used hypersaline soda lakes as a characteristic inhabitants ( e.g. the lakes of Wadi Natrun in Egypt, Tibet and Certain in China, and Magadi in Kenya) [44]. These archaeal could grow approximately at $\mathrm{pH} 12$, the greatest $\mathrm{pH}$ of all living organisms.

Microorganism enzymes, which can survive under alkalis have efficiency for many applications such as the production of detergents[45]. Internally, the striking of alkaliphilic properties of microorganismsare to maintain a neutral $\mathrm{pH}$, so the adaptation to extreme growing conditions for the intracellular enzymes is not required. This advantage is not including the extracellular proteins. Alkaliphiles enzymes have ability to resistant high concentration of detergents and showing their optimum activity at high $\mathrm{pH}$ such as lipases, amylases, and proteases. Based on PCR homology combinations, the alkaline proteases have been isolated from hot environments by collecting thermoacidophilic bacteria and archaea [46]. 
Extremophile Current Challenges and New Gate of Knowledge by Nanoparticles Pathways.

\subsection{High saline}

Salt is a commonrequirement in marine bacteria which stay in environmentalsalts $(30-35 \mathrm{~g} / \mathrm{l})$. Microorganisms of extremely halophilic could be survived at higher salt concentrations that equal to the saturation of $\mathrm{NaCl}(300 \mathrm{~g} / \mathrm{l})$. For example, the inhabitant of halophilic microorganisms in theDead Sea (between Jordon and Palestine) which has about $340 \mathrm{~g} / 1$ salt concentration, with $0.4 \mathrm{M} \mathrm{Ca}^{2+}$ and more than 1.9 $\mathrm{MMg}^{2+}$.Haloalkaliphilic microorganisms, Natronococcus and Natronobacterium, are extreme halophilic that found in soda lakes. The lakes of salt such as hypersaline alkaline lakes, Great Salt Lake (Utah), the Dead Sea, and the crystallizer ponds of $\mathrm{NaCl}$-saturated for solar salterns production are probably red color. The appearance of reddish color indicate the presence of rhodopsins and carotenoids with high density of the halophilic Archaea communities of Halobacteriaceae family [44, 47, 48]. Moreover, halophilic archaea could be useful in fermentation of some foods like kimchi (a popular Korean dish)[49]. Some species ofunicellular green algae Chlorophyta (genus of Dunaliella) could participate in brine coloration. The $\beta$-carotene of massive accumulation that produced by algae could lead to red-orange color. Bacterial domain has extremely halotolerant or halophilic species, including sulfate reducers, fermentative species, aerobic heterotrophs, as well as the bacterial of anoxygenic photosynthetic sulfur (Halochromatium, Halorhodospira), and oxygenic phototrophs (cyanobacteria) [44].

Also, in hypersaline habitats the halophiles can be survived by maintaining of osmotic balance as compatible solute production and biofilm formation [50]. Compatible solution including proline, glutamate, carnitine, betaine, glycine, ectoine, and exotic compatible solutes as 2-sulfotrehalose[51, 52].In environmental isotonic, the accumulation of salts like $\mathrm{KCl}$ or $\mathrm{NaCl}$ are in equal concentrations. As a results, the concentration of high salts have been copied by halophilic proteins (e.g. concentrations of $\mathrm{NaCl}$ and $\mathrm{KCl}$, going to be $>5 \mathrm{M}$ and $4 \mathrm{M}$ respectively) $[53,54]$. Halophilic enzymes can degrade some chemicals in high salt concentration such as phenols[55]. In environmental pressure, the enzymes adapted to prevent precipitation by earning a large number of relatively negative charge amino acids on their surfaces. Therefore, the application of halophilic enzymes are probably very poor and limited due tolower solubility in salt concentration [56]. However, the advantage of this property could be carrying by using halophilic enzymes in nonaqueous and aqueous/organic media [57]. Halobacteriumhalobium extracellular protease exploiting to synthesize efficient peptide in $\mathrm{N}^{\prime}$-N'-dimethylformamide [58]. In very lower concentrations of salt, the reversed micelles of enzyme entrapped by using Halobacteriumsalinarum p-nitrophenylphosphate phosphatase (p-NPPase) [59]. In same conditions, the stability and activity of p-NPPase is same as halophilic malate dehydrogenase [60]. The advantage of halophilic enzymes with reversed micelles are promising to develop novel applications of enzymes[61].

\subsection{Pressure}

Sincethe oceans depth is probably in average of 4 to $11 \mathrm{~km}$ as a maximum,the high pressure degree is observed. One atmosphere $(0.1 \mathrm{MPa})$ of hydrostatic pressure has been increased for every ten meter depth. In near Philippines (Mariana Trench), the deepest sea point pressure is about $110 \mathrm{MPa}$. The presence of halophilic, alkaliphilic, acidophilic, and thermophilic microorganismsin the deep sea, may help in finding a little relative about inhabiting the bacterial pressureloving (piezophiles or barophiles). In the last decade, the first bacterial truth piezophile (generally polyextremophiles) has been isolated and characterized. In the deep sea, they found piezophilic bacteria and in the same time being psychrophilic or thermophilic bacteria[62, 63].The truly piezophilic bacteria (rather than piezotolerant) need to growth at least on $0.1 \mathrm{MPa}$ as minimum and 10-50 MPaas optimum pressureor more. Accordingly, the $\gamma$-branch of the Proteobacteria in the genera of Shewanella and Moritella which obtained from the Mariana Trench in $11 \mathrm{~km}$ depth have optimum growth pressures 70 and $80 \mathrm{MPa}$, respectively, however, theycould not grow up below $50 \mathrm{MPa}$ [64]. In the deep sea of Philippine and Japan Trench, the optimum growth ratio of piezophilic strains isolated from the group of Shewanellais 50-70 $\mathrm{MPa}$ at $10{ }^{\circ} \mathrm{C}$ [65]. In the archaeal domain, there are piezophiles in the hydrothermal vent of Mid-Atlantic Ridge found as a hyperthermal Themococcusbarophilus. For growing up they required high pressure with optimum temperature $100^{\circ} \mathrm{C}[66]$. Yayanos et al, isolated most of barophilic strains (probably MT41) from the Mariana Trench under highest pressure 130MPa [67, 68]. Several barophiles needing a complex system and devices such as complex gas systems andhydraulic pumpsto maintain the optimum pressure [69].

The major selectivity force of the pressure dose not exert in protein function[70].There is assumption that if the pressure exceed $400 \mathrm{MPa}$ it will induce a single chain in proteins denaturation. In fact, the above assumption it seems impossible because the microorganisms could not exceeding $400 \mathrm{MPa}$ even that living in the deep sea (exceeding at most $120 \mathrm{MPa}$ [70]. Accordingly, their enzymes does not requiring a specific pressure related adaptation. However, some examples using high pressure for the stabilization of specific protein $[71,72]$. In food production, the application of food material sterilization and processing being in high pressure that is why protein pressure resistant can be used[73]. In the previous decade, the opportunities of 
piezophiles biotechnology have been reviewed [74]. Piezophiles with extremely temperature have adaptation number as a primarily deal, but they may contain unique adaptation numbers which have high pressure conditionssuch as multimeric protein propensities as well as dense hydrophobic cores. All of these adaptations are already studied [75]. On the other hand, barophiles have cell membranes adaptation uniquely to adapt the pressure[76]. There is nothing reported in barophilic NPs [77].

\section{Nanoparticles Synthesis}

Nanoparticles ( NPs) are a promising at the last decade that can be using for energy production, environmental sectors, electronics, and biomedical applications [78-81]. Different materials produce NPs engineering that could be have many characteristics of chemicals e.g. silica, carbon, multipolymers and other metals or biological origins e.g. chitosan, dextran, lactic acids, phospholipids, lipids, and proteins[82]. NPs utilized for therapy and diagnosis in medicine that according to their special characterizes (e.g. relatively large surface area, high number concentration, and ultra-small size) which support the researchers to passing all limitation of therapeutic agent and traditional diagnosis [83-85]. These special characterizes can help to finding the presenting of novel biomarker by new devices development.

Extreme microorganisms can be as a factory to synthesize inorganic nanoparticles (NPs) such as gold $(\mathrm{Au})$ and silver $(\mathrm{Ag})$ NPs. For example, Geobacillus sp.ID17 provides a special pathways andcould be considered as a novel organism that has ability to synthesize NPsby NADH- dependent mechanism. It should be mentioned that this kind of bacteriasynthesize AuNP under high temperatures and involving four capacities of unknown enzymes. Moreover, intracellular quasi-hexagonal NPs (5-50nm)have been produced by ID17 when challenged in potassium phosphate buffer $(20 \mathrm{mM})$ and hydrogen tetrachloroaurate $(1 \mathrm{mM})[86]$.

Due to stability of this thermophilic organism (at $65^{\circ} \mathrm{C}$ ), the NPs can be designed ascapped proteins.

Thermotolerant fungus such as Kluyveromyces marxianus synthesized complete extracellular spherical Ag-NPs (3-12 nm), whichcharacterized by anti-fungal activities and stabilityof proteins capping [87]. ComparedwithStreptomyces sp.,Aspergillus fumigatusshows high efficiencyin stability of Ag-NPs production and size (range between 15-45 nm). Further information, the capping of NPs reduce Ag by passing the mechanism of NADH-reductase[88].Cryptococcus laurentii producing an extracellular stable Ag-NPs by the supernatant of cell-free, however, the psychrotrophic yeast such as Yarrowia lipolytica NCYC 789 producingan intracellular Ag-NPsunder submerged condition in the medium containing yeast nitrogen base glucose $[89,90]$ BacillusNARW11 was able to produce titanium oxideat $\mathrm{pH} 2$ with a tolerate temperature at $50^{\circ} \mathrm{C}$ that used for fluoride adsorption[91].Alcaligenesfaecalishas efficient ability to produce antimicrobial Ag-NPs under condition of alkali tolerantand non-nitrate reduction[92, 93].The synthesisprocess of cell-free supernatant was optimized at $60{ }^{\circ} \mathrm{C}$ and at $\mathrm{pH} 10$. Attenuated total reflection-Fourier transform infrared spectroscopy(ATR-FTIR) was used for determination of the existence of stabilizing NPs in capping protein [93]. The organism of nitrate lacking reduction provide a novel way for producing stable Ag-NPs[94].

The halophilic marine fungusAspergillussydowii (recognized as bio-factory) has capability to produce gold NPs in highly specific pattern[95, 96]. While, $H$. salifodinae BK3 of halo-archaea categorized as Ag-NPs biosynthesis[97].This kind of halo-archaea maintain the surrounding osmotic balance byincreasing the concentration of $\mathrm{K}^{+}$within their cells. Spherical morphology of crystalline structured Ag-NPs have been identified as intracellular production, e.g. H. salifodinaeincreasing the growth of microorganism over time and develop silver tolerance [97].

\section{Conclusion}

This study interested to present from arise of extremophiles to new gate of extremophile nanoparticles synthesized pathwaysto explain some of extremophiles conditions such as temperatures, $\mathrm{pH}$,saline, pressures, and in combination of several conditions. Also it shed light on the unique organisms which could be a promise candidate in different application of industrials. Finally, some ofmetallic NPs provided effective extremophiles synthesized pathway.

\section{References}

[1]. López-García, Chapter of Extremophiles, Lectures in Astrobiology. Part of the series Advances in Astrobiology and Biogeophysics, 2005. pp (657-679)

[2]. Farlow, W.G., On the nature of the peculiar reddening of salted codfish during the summer season. U.S. Commission of Fish and Fisheries, 1880 pp(969-974).

[3]. B, W., Life in the Dead Sea. Nature, 1936. 138, 467.

[4]. E, W.C.R.a.F.G., Phylogenetic structure of the prokaryotic domain: the primary kingdoms Proc. Natl. Acad. Sci. USA 1977. 74(5088-5090).

[5]. Brock T. D, F.H., Thermus aquaticus gen. n. and sp. n., a nonsporulating extreme thermophile. J. Bacteriol, 1969 98( 289-297).

[6]. Brock T. D., B.K.M., Belly R. T. and Weiss R. L, Sulfolobus: a new genus of sulfur-oxidizing bacteria living at low pH and high temperature Arch Mikrobiol 1972. 84(54-68). 
[7]. Madigan M. T., M.J.M.a.P.J., Brock Biology of Microorganisms, 10th edn. New Jersey: Prentice-Hall, Inc., 2002.

[8]. Elena V. Pikuta, R.B.H.a.J.T., Microbial Extremophiles at the limits of life Critical Reviews in Microbiology, 2007. 33:182-209(1549-7828).

[9]. Stetter, K.O., Hyperthermophilic Microorganisms. Astrobiology, 2002.

[10]. Eleni Gomes, A.R.d.S., Guillermo Ladino Orjuela, and T.B.d.O. Roberto Da Silva, and Andre Rodrigues, Applications and Benefi ts of Thermophilic Microorganisms and Their Enzymes for Industrial Biotechnology. Gene Expression Systems in Fungi:Advancements and Applications, Fungal Biology,, 2016. DOI 10.1007/978-3-319-27951-0_21.

[11]. Stetter, K.O., Extremophiles and their adaptation to hot environments FEBS Letters 1999. 452 (22-25).

[12]. Woese, C.R., Kandler, O. and Wheelis, M.L., Towards a natural system of organisms: Proposal for the domains Archaea, Bacteria, and Eucary. Acad. Sci. , 1990. USA 87(4576-4579).

[13]. Woese, C.R.a.F., G.E, Phylogenetic structure of the prokaryotic domain: The primary kingdoms. Acad. Sci, 1977. USA 74(5088-5090.).

[14]. Stetter, K.O., Colloque Interdisciplinaire du Comite National de la Recherche Scientiфque, Frontiers of Life (Tra "n Thanh Va "n, J.K., Mounolou, J.C., Schneider, J. and Mc Kay,C., Eds.),, 1992. pp.( 195-219).

[15]. Vieille C, Z.G., Hyperthermophilic enzymes: sources, uses, and molecular mechanisms forthermostability. Microbiol Mol Biol Rev. , 2001. 65:1-43. (1092-2172).

[16]. Huber R, L.T., König H, Thomm M, Woese C, Sleytr U, Stetter K., Thermotoga maritimasp. nov. represents a new genus of unique extremely thermophilic eubacteria growing up to $90^{\circ} \mathrm{C}$. Arch Microbiol., 1986. 144:(324-33).

[17]. Hedlund BP, C.J., Williams AJ, Hou W, Zhou E, Li W, Dong H., A review of the microbiology of the Rehai geothermal field in Tengchong, Yunnan Province, China. . Geosci Front., 2012. 3(273-88).

[18]. Berlemont R, G.C., 1.18-Extremophiles. In: Moo-Young M, editor. Comprehensive biotechnology. 2nd ed. Burlington: Academic, 2011. p. (229-42.).

[19]. Elleuche S, S.C., Blank S, et al., Exploration of extremophiles for high temperature biotechnological processes. Curr Opin Microbiol, 2015. 25(113-119).

[20]. Paiardini A, G.G., Bossa F, Pascarella S, Structural plasticity of thermophilic serine hydroxymethyltransferases. Proteins 2002. $\mathbf{5 0}(122-134)$.

[21]. K, T., Overview of thermostable DNA polymerases for classical PCR applications: From molecular and biochemical fundamentals to commercial systems. . Appl Microbiol Biotechnol, 2013. 97(10243-10254).

[22]. Sterner R, L.W., Thermophilic adaptation of proteins. . Biochem Mol Biol 2001. 36(39-106).

[23]. Vieille C, Z.G., Hyperthermophilic enzymes: sources, uses, and molecular mechanisms for thermostability. . Microbiol Mol Biol Rev 2001. 65(1-43).

[24]. Van den Burg B, E.V., Selection of mutations forincreased protein stability. . Curr Opin Biotechnol, 2002. 13(333-337).

[25]. Joly M, A.E., Sancelme M, Ice nucleation activity of bacteria isolated from cloud water. . Atmos Environ, 2013. 70(392-400).

[26]. OREN, J.S.a.A., INTRODUCTION TO THE EXTREMOPHILES. Chapter Origins, Life in Extreme Habitats and Astrobiology 2004. 6 of the series Cellular Origin( 371-396).

[27]. James Charlesworth, B.P.B., Extremophilic adaptations and biotechnological applications in diverse environments. AIMS Microbiology, 2016. 3(251-261).

[28]. Staley, J.T., and Gosink, J.J. , Poles apart: biodiversity and biogeography of sea ice bacteria. Ann. Rev.Microbiol. , 1999. 53(189-215).

[29]. Vorobyova, E., Soina, V., Gorlenko, M., Minkovskaya, N., Zalinova, N., Mamukelashvili, A., Gilichinsky, and R. D., E., and Vishnivetskaya, T, The deep cold biosphere: facts and hypothesis. FEMS Microbiol. Rev, 1997. 20(277-290).

[30]. Rivkina, E.M., Friedmann, E.I., McKay, C.P., and Gilichinsky, D.A, Metabolic activity of permafrost bacteria below the freezing point Appl. Environ. Microbiol, 2000. 66( 3230-3233).

[31]. Irgens, R.L., Gosink, J.J., and Staley, J.T, Polaromonas vacuolata gen. nov., sp. nov., a psychrophilic marine, has-vacuolate bacterium from Antarctica. Int. J. Syst. Bacteriol, 1996. 46(822-826).

[32]. Pick, U., Dunaliella acidophila - a most extreme acidophilic alga, In: Seckbach, J. (ed.), Enigmaticmicroorganisms and life in extreme environments. . Kluwer Academic Publishers, Dordrecht., 1999. pp(467-478).

[33]. Elleuche S, S.C., Sahm K, Antranikian G, Extremozymes-biocatalysts with unique properties from extremophilic microorganisms. Curr Opin Biotechnol, 2014. 29(116-123).

[34]. Seckbach, J.e., Evolutionary pathways and enigmatic algae: Cyanidium caldarium (Rhodophyta) andrelated cells. . Kluwer Academic Publishers, Dordrecht., 1994.

[35]. Seckbach, J.e., Enigmatic microorganisms and life in extreme environments. Kluwer Academic Publishers Dordrecht, 1999.

[36]. Schleper, C., Pühler, G, Kühlmorgen, B. and Zilllig, W., Life at extremely low pH. Nature 1995a. 375(741-742).

[37]. Schleper, C., Pühler, G., Holz, I., Gambacorta, A., Janovic, D., Santarius, U., Klenk, H.P., and Zillig, W, Picrophilus gen. nov., fam. nov.: a novel aerobic, heterotrophic, thermoacidophilic genus and family comprising archaea capable of growth around pH 0 . J. Bacteriol, 1995b. 177(7050-7059).

[38]. Schleper, C., Pühler, G., Klenk, H.-P., and Zillig, W, Picrophilus oshimae and Picrophilus torridus fam. nov., gen. nov., sp. nov., two species of hyperacidophilic, thermophilic, heterotrophic, aerobicarchaea Int. J. Syst. Bacteriol, 1996. 46(814-816).

[39]. Stetter, K.O., Hyperthermophiles: isolation, classification and properties, In: Horikoshi, K., and Grant, W.D. (eds.), Extremophiles: Microbial life in extreme environments. Wiley-Liss, Inc., New York, 1998. pp(1-24).

[40]. Bertoldo C, A.G., Starch-hydrolyzing enzymes from thermophilic Archaea and bacteria. Curr Opin Chem Biol 2002. 6(151-160).

[41]. Serour E, A.G., Novel thermoactive glucoamylases from the thermoacidophilic Archaea Thermoplasma acidophilum, Picrophylus torridus and Picrophilus oshhimae.. Antonie Van Leeuwenhoek 2002. 81(73-83).

[42]. Zavarzin, G.A., and Zhilina, T.N, Anaerobic chemotrophic alkaliphiles, In: Seckbach, J. (ed.) Journey to diverse microbial worlds. Adaptation to exotic environments. Kluwer Academic Publishers, Dordrecht., 2000. pp(193-208).

[43]. Zhilina, T.A., and Zavarzin, G.A, Alkaliphilic anaerobic community at pH 10. Curr. Microbiol, 1994. 29(109-112).

[44]. Oren, A., Halophilic microorganisms and their environments. Kluwer Academic Publishers, Dordrecht., 2002.

[45]. Fujinami S, F.M., Industrial applications of alkaliphiles and their enzymes - past, present and future. . Environ Technol, 2010. 31(845-856).

[46]. Kocabiyik S, E.B., Intracellular alkaline proteases produced by thermoacidophiles: detection of protease activity by gelatin zymography and polymerase chain reaction (PCR). Bioresource Technol, 2002. 84(29-33).

[47]. Oren, A., Life at high salt concentrations. In: Dworkin, M., Falkow, S., Rosenberg, E., Schleifer, K. -H., and Stackebrandt, E. (eds.), The Prokaryotes. A handbook on the biology of bacteria: ecophysiology, isolation, identification, applications. 3rd. ed. Springer-Verlag, New York (electronic publication) (release 3.1), 2000a. 
[48]. Oren, A., The order Halobacteriales. In: Dworkin, M., Falkow, S., Rosenberg, E., Schleifer, K.-H., and Stackebrandt, E. (eds.), The Prokaryotes. A handbook on the biology of bacteria: ecophysiology, isolation, identification, applications 3rd. ed. Springer-Verlag, New York (electronic publication) (release 3.2). 2000b.

[49]. Chang HW, K.K., Nam Y Do, Analysis of yeast and archaeal population dynamics in kimchi using denaturing gradient gel electrophoresis. Int J Food Microbiol, 2008. 126(159-166).

[50]. S, F., Archaeal biofilms: widespread and complex. Biochem Soc Trans, 2013. 41(393-8).

[51]. Goh F, J.Y., Barrow K, Osmoadaptive strategies of the archaeon Halococcus hamelinensis isolated from a hypersaline stromatolite environment. . Astrobiology 2011. 11(529-36).

[52]. Youssef NH, S.-A.K., McCully AL., Trehalose/2-sulfotrehalose biosynthesis and glycine-betaine uptake are widely spread mechanisms for osmoadaptation in the Halobacteriales. ISME J 2014. 8(636-49).

[53]. Demirjian DC, M.-V.F., Cassidy CS, Enzymes from extremophiles. Curr Opin Chem Biol 2001. 5(144-151).

[54]. Danson MJ, H.D., The structural basis of protein halophilicity. Comp Biochem Physiol, 1997. 117A(307-312).

[55]. Wang YF, W.X., Li H., Treatment of high salinity phenol-laden wastewater using a sequencing batch reactor containing halophilic bacterial community. Int Biodeterior Biodegrad, 2014. 93(138-144).

[56]. Madern D, E.C., Zaccai G, Halophilic adaptation of enzymes. Extremophiles 2000. 4(91-98).

[57]. AM, K., Improving enzymes by using them in organic solvents Nature 2001. 409(241-246).

[58]. Kim J, D.J., Unusual salt and solvent dependence of a protease from an extreme halophile. Biotech Bioeng, 1997. 55(471-479).

[59]. Marhuenda-Egea FC, P.-V.S., Cadenas C, Cadenas E, An extreme halophilic enzyme active at low salt in reversed micelles. J Biotechnol, 2002. 93(159-164).

[60]. Piera-Velazquez S, M.-E.F., Cadenas E, The dependence of a halophilic malate dehydrogenase on xo and surfactant concentration in reversed micelles. . J Mol Catal B Enzym, 2001. 13(49-55).

[61]. Marhuenda-Egea F, B.M., Extreme halophilic enzymes in organic solvents. Curr Opin Biotechnol 2002. 13(385-389).

[62]. Jebbar M, F.B., Girard E, Oger P, Microbial diversity and adaptation to high hydrostatic pressure in deep-sea hydrothermal vents prokaryotes. . Extremophiles 2015. 19(721-740).

[63]. Hay S, E.R., Levy C, Are the catalytic properties of enzymes from piezophilic organisms pressure adapted? . ChemBioChem, 2009. 10(2348-2353).

[64]. Kato D, L.L., Nogi Y, Nakamura Y, Tamaoka J,Horikoshi K. , Extremely barophilic bacteria isolated from the Mariana Trench, Challenger Deep, at a depth of 11,000 meters. Appl. Environ. Microbiol 1998. 64(1510-1513).

[65]. Kato, C., and Bartlett, D.H., The molecular biology of barophilic bacteria. Extremophiles 1997. 1(111-116).

[66]. Marteinsson, V.F., Birrien, J.-L., Reysenbach, A.-L., Vernet, M., Marie, D., Gambacorta, A., Messner, P., Sleytr, U.B., and Prieur, D. , Thermococcus barophilus sp. nov., a new barophilic and hyperthermophilic archaeon isolated under high hydrostatic pressure from a deep-sea hydrothermal vent. Int. J. Syst. Bacteriol., 1999. 49(351-359).

[67]. Yayanos, A.A., Dietz, A.S., and van Boxtel, R. , Obligately barophilic bacterium from the Mariana Trench. . Proc. Natl. Acad. Sci. USA 1981. 78(5212-5215).

[68]. Yayanos, A.A., Evolutional and ecological implications of the properties of deep-sea barophilic bacteria. Proc. Natl. Acad. Sci. USA 1986. 83(9542-9546).

[69]. Zhang Y, L.X., Xiao X, Bartlett DH, Current developments in marine microbiology: High-pressure biotechnology and the genetic engineering of piezophiles. Curr Opin Biotechnol, 2015. 33(157-164).

[70]. Gros M, J.R., Protein under pressure. Eur J Biochem, 1994. 221(617-630).

[71]. Pledger RJ, C.B., Baros JA, A barophilic response by two hyperthermophilic, hydrothermal vent Archaea: an upward shift in the optimal temperature and acceleration of growth rate at supra-optimal temperatures by elevated pressure. FEMS Microbiol Ecol, 1994. 14(233-242).

[72]. Hei DJ, C.D., Pressure stabilization of proteins from extreme thermophiles. Appl Environ Microbiol, 1994. 60(932-999.).

[73]. H., Use of high pressure in bioscience and biotechnology. In High pressure Bioscience and Biotechnology. Elsevier, 1996(1-6).

[74]. Abe F, H.K., The biotechnological potential of piezophiles. . Trends Biotechnol, 2001. 19(102-108).

[75]. Reed CJ, L.H., Trejo E, Protein adaptations in archaeal extremophiles. Archaea, 2013.

[76]. Usui K, H.T., Kawamoto J, Eicosapentaenoic acid plays a role in stabilizing dynamic membrane structure in the deep-sea piezophile Shewanella violacea: A study employing high-pressure time-resolved fluorescence anisotropy measurement. . Biochim Biophys Acta -Biomembr, 2012. 1818(574-583).

[77]. Erik Beeler, O.V.S., Extremophiles as sources of inorganic bio-nanoparticles. World J Microbiol Biotechnol 2016. 32(156).

[78]. Bao G, M.S., Tong S, Multifunctional nanoparticles for drug delivery and molecular imaging. Annu Rev Biomed Eng, 2013. 15(253-282).

[79]. Stehlik S, P.T., Girard H A, Nanoparticles assume electrical potential according to substrate, size, and surface termination. Langmuir, 2013. 29 (5)(1634-1641).

[80]. Ramsurn H, G.R.B., Nanotechnology in Solar and Bio Fuels. ACS Sustainable Chemistry \& Engineering, 2013.

[81]. Shah V, C.D., Walker V K, The impact of engineered cobalt, iron, nickel and silver nanoparticles on soil bacterial diversity under field conditions. Environmental Research Letters, 2014. 9 (2)(024001).

[82]. Radad K, A.-S.M., Moldzio R, Recent advances in benefits and hazards of engineered nanoparticles. Environ Toxicol Pharmacol, 2012. 34 (3)(661-672).

[83]. Parveen S, M.R., Sahoo S K, Nanoparticles: a boon to drug delivery, therapeutics, diagnostics and imaging. Nanomedicine 2012. 8 (2)(147-166).

[84]. Cho K, W.X., Nie S, Therapeutic nanoparticles for drug delivery in cancer. Clin Cancer Res, 2008. 14 (5)(1310-1316).

[85]. Kumar A, Z.X., Liang X J, Gold nanoparticles: emerging paradigm for targeted drug delivery system. Biotechnol Adv, 2013.31 (5)(593-606).

[86]. Correa-Llante 'n DN, M.o.-I.S., Castro ME, Mun oz PA, Blamey JM, Gold nanoparticles synthesized by Geobacillus sp. strain ID17 a thermophilic bacterium isolated from deception island, Antarctica. . Microb Cell Fact 2013. 12(75).

[87]. SM, A., Silver nanoparticles as antimicrobial agent from Kluyveromyces marxianus and Candida utilis. Int J Curr Microbiol Appl Sci, 2014. 3(384-396).

[88]. Alani F, M.-Y.M., Anderson W Biosynthesis of silvernanoparticles by a new strain of Streptomyces sp. compared with Aspergillus fumigatus. . World J Microbiol Biotechnol, 2012. 28(1081-1086. ).

[89]. Ortega FG, F.n.-B.M., Ferna 'ndez JG, Serrano MJ, Sanz MI, Diaz-Mocho 'n JJ, Lorente JA, Raba J Study of antitumor activity in breast cell lines using silver nanoparticles produced by yeast. Int J Nanomedicine, 2015. 10(2021-2031).

[90]. Apte M, S.D., Gaikawad S, Joshi S, Bankar A, Kumar AR, Zinjarde S Psychrotrophic yeast Yarrowia lipolytica NCYC 789 mediates the synthesis of antimicrobial silver nanoparticles via cell-associated melanin. . AMB Express, 2013. 3(32). 
[91]. Suriyaraj SP, V.T., Biji P, Selvakumar R, Adsorption of fluoride from aqueous solution using different phases of microbially synthesized TiO2 nanoparticles. J Environ Chem Eng, 2014. 2(444-454).

[92]. Wang X, Y.P., Zeng C, Ding H, Li Y, Wang C, Lu A, Enhanced Alcaligenes faecalis denitrification rate with electrodes as the electron donor. Appl Environ Microbiol, 2015. 81(5387-5394).

[93]. El-deeb B, M.N., Altalhi A, Gherbawy Y, Extracellular biosynthesis of silver nanoparticles by bacteria Alcaligenes faecalis with highly efficient anti-microbial property. Int J Chem Eng, 2013. 30(1137-1144).

[94]. Singh P, K.Y., Zhang D, Yang DC, Biological synthesis of nanoparticles from plants and microorganisms. . Trends Biotechnol S0167-7799, 2016. 16(00040-00048).

[95]. AK, V., Exploration on green synthesis of gold nanoparticles by a marine-derived fungus Aspergillus sydowii. . Environ Prog Sustain Energy, 2015. 34(94-197).

[96]. Gunde-Cimerman N, Z.P., Extremely halotolerant and halophilic fungi inhabit brine in solar salterns around the globe. Food Technol Biotechnol, 2014. 52(170-179)

[97]. Srivastava P, B.a.J., Ramanan SR, Kowshik M, Synthesis of silver nanoparticles using haloarchaeal isolate Halococcus salifodinae BK3. Extremophiles 2013. 17 (5)(821-831) 